\title{
Nata de ceulerpa from sea grape fermentation (Caulerpa racemosa) by Acetobacter xylinum as a functional food rich in vitamin $\mathrm{C}$
}

\author{
J.I.C. Manoppo ${ }^{1}$, F. Nurkolis ${ }^{2}$, S.C. Batubara ${ }^{3}$, R. Rompies ${ }^{1}$, N. Mayulu ${ }^{4}$, Y.A. Assa ${ }^{4}$, \\ H. Natanael ${ }^{1}$, D.S. Wewengkang ${ }^{5}$ and H. Rotinsulu ${ }^{5}$ \\ ${ }^{1}$ Department of Pediatrics, Sam Ratulangi University/Prof.dr.R.D.Kandou Hospital Manado, Manado, North Sulawesi, \\ Indonesia, \\ ${ }^{2}$ Department of Biological Sciences, Faculty of Sciences and Technology, State Islamic University of Sunan Kalijaga, \\ Yogyakarta, Indonesia, \\ ${ }^{3}$ Department of Food Sciences and Technology, Faculty of Food Technology and Health, Sahid University of Jakarta, \\ South Jakarta, Jakarta, Indonesia, \\ ${ }^{4}$ Food and Nutrition Department of Sam Ratulangi University, Kampus Unsrat Bahu Street, Manado, Indonesia and \\ ${ }^{5}$ Pharmacy Department of Sam Ratulangi University, Kampus Unsrat Bahu Street, Manado, Indonesia
}

Nata is a food product made by fermentation using A. xylinum bacteria. On the market that is often found is nata made from coconut. However, by looking at the potential of the Ceulerpa racemosa type of sea grape which has the potential to be used as Nata de ceulerpa which is rich in minerals and vitamins and antioxidants ${ }^{(1)}$ and is still little use for food and health products. Therefore, this study aims to process or formulate and utilize sea grapes (Ceulerpa racemose) into nata de ceulerpa food products and determine the content of vitamin $\mathrm{C}$ in it.

The A. xylinum starter bacterium was obtained from pineapple (Ananas comosus). The pineapple pulp was mixed with water and sugar in a ratio of 6: $3: 1(\mathrm{w} / \mathrm{v} / \mathrm{w})$, the mixture stirred until evenly distributed, and then put in a bottle (500ml) until it was half the contents. Then the bottle that has been filled with pineapple covered with a clean cloth or paper and stored in a safe place and left for 2-3 weeks until a white layer formed on it (this layer is a colony of Acetobacter xylinum bacteria). The sea grapes were first refined using a blender. There were 3 variations of the formulation, sea grape: sugar: A. xylinum starter water. Sample 1 (1: 0.50: 0.50), sample 2 (1: 0.25: 0.75) and sample 3 (1: 0.15: 1). Then each sample was incubated for 14 days with a pH ranging from 4-4.5. The nata de ceulerpa product was then analysed for antioxidant levels (Vitamin C) using the iodometric titration method in $\mathrm{mg} / 100 \mathrm{~g}$. The test on each samples is done in triplicate (triple). ANOVA Statistical tests were used in the difference between the vitamin c levels of the three samples.

The amount of vitamin C obtained at S1 $80.40 \pm 1.00 \mathrm{mg} / 100 \mathrm{~g}, \mathrm{~S} 275.64 \pm 2.00 \mathrm{mg} / 100 \mathrm{~g}, \mathrm{~S} 371.90 \pm 0.02 \mathrm{mg} / 100 \mathrm{~g}$. The fermented drink sample formulation containing the highest vitamin $\mathrm{C}$ was $\mathrm{S} 1$. There was a significant difference $(\mathrm{P}<0.05)$ which determined the vitamin $\mathrm{C}$ levels between the sample formulations. The average ash content of the three samples was $1.30 \pm 0.3 \%$ and the moisture content was $25.60 \pm 2.51 \%$.

The sea grape type Ceulerpa racemosa has the potential to be used as a processed product, namely nata de ceulerpa. S1 sample is the best formulation, this is possible because of the higher sugar content and bacterial concentration compared to S2 and S3 samples. Furthermore, the average levels of vitamin $\mathrm{C}$ which is also an antioxidant in the three samples amounted to $75.98 \pm 4.26 \mathrm{mg} / 100 \mathrm{~g}$, a value that is quite high compared to Nata De Coco which must be fortified with vitamin $\mathrm{C}^{(2)}$. Thus, nata de ceulerpa has the potential to be a functional food that can be used as a source of vitamin $\mathrm{C}$ or antioxidants, which antioxidants or vitamin $\mathrm{C}$ are useful in warding off free radicals, being an anti-inflammatory and anti-non-communicable diseases ${ }^{(3)}$.

\section{Acknowledgements}

The authors' responsibilities were as follows - all authors: contributed to the writing and revisions contained in the abstract as Original Communications. We thank to all of contributors for their outstanding help in formatting the abstract, especially Fahrul Nurkolis who has fully assisted in laboratory tests.

\section{References}

1. Gaillande C, Payri C, Remoissenet G, et al. (2017) J Appl Phycol 29(5), 2249-2266.

2. Sihmawati RR \& Oktoviani D (2014) HEURISTIC: J Teknik Industri, 11(02).

3. Jayedi A, Rashidy-Pour A, Parohan M, et al. (2018) Adv Nutr 9(6), 701-716. 